The constrictor responses to cold were still present, this suggesting that the neural pathways for the reflex were intact. Some of the patients had been taking ergot, but the drug was stopped 48 hours before testing. It is doubtful if this is long enough to eliminate the effects of prolonged ergot therapy, but vasoconstriction persisted in a patient who had never had the drug, and the two who showed a normal response had both been taking it.

This work supports the suggestion that there is a general abnormality of vascular behaviour in many migrainous subjects, and it may be that the site of pain is determined by the liberation locally of the humoral agent "neurokinin" described by L. F. Chapman and co-workers, ${ }^{6}$ which lowers the patient's pain threshold in relation to his cranial arteries and further stimulates their dilatation. Whether such disturbances originate peripherally or centrally is not clear and many problems remain unanswered. They need continued study, for the disorder is common and disabling and the reservoir of clinical material is enormous.

The difficulties in providing effective drug treatment for migraine are well known, though with care much can be done to help these unfortunate patients. Dr. J. Crooks, Dr. S. A. Stephen, and Mr. W. Brass report at page 221 of this week's B.M.F. on the value of ergotamine by inhalation. It appeared to be of great help to some of the patients, but the contraindications to it (which they discuss) need to be borne in mind. Reporting on a series of twenty patients with an allied disorder-periodic migrainous neuralgia-Drs. J. I. Balla and J. N. Walton (page 219) emphasize the importance of early diagnosis, for treatment can be exceedingly helpful. An ergotamine preparation prescribed prophylactically gave complete or almost complete relief in more than half their twenty cases.

\section{Intrahepatic Cholestasis}

Patients with obstructive jaundice usually give little difficulty in diagnosis. But there is a small group in whom clinical, biochemical, and sometimes histological features fail to differentiate extrahepatic from intrahepatic obstruction. The latter has been termed intrahepatic cholestasis. ${ }^{1}$ Interest in it has increased in recent years because it is now known to occur in some forms of infectious hepatitis ${ }^{2} 3$ and of druginduced jaundice, both characterized by prolonged, painless jaundice. Many drugs, notably phenothiazine derivatives and anabolic steroids, may cause this type of intrahepatic cholestasis. ${ }^{4}$ While infective hepatitis and drugs remain the chief causes of the syndrome, it is clear that there are others -for example, idiopathic jaundice of pregnancy ${ }^{5}$ and benign recurrent obstructive jaundice. ${ }^{\circ}$ And intrahepatic cholestasis may complicate acute alcoholic hepatitis, ${ }^{8}$ postnecrotic cirrhosis, ${ }^{9}$ and Hodgkin's disease. ${ }^{10}$

The cause of the intrahepatic obstruction is obscure, even in those cases such as cirrhosis and Hodgkin's disease in which a mechanical block might seem to exist. The histological appearance is remarkably constant. Bile stasis is seen in the canaliculi, particularly in the centrilobular region. Scattered bile thrombi are present and bile appears in occasional liver cells and Kupffer cells. Proliferation of bile ducts-a feature of extrahepatic obstruction-occurs only in the later stages. The liver cells look surprisingly healthy, though " feathery degeneration" may be seen if the jaundice is prolonged.
Patchy infiltration with round cells in the portal tracts is a variable feature. Changes in the lining of the canaliculi have been reported on electron microscopy, ${ }^{11}$ and there may be increased permeability in the canaliculi or ductules. A more likely explanation, however, is that there is some physicochemical alteration in the nature of the bile, perhaps the result of hypersensitivity. The higher incidence of intrahepatic cholestasis in women than in men, the propensity for anabolic steroids to cause it, and its greater frequency in the last than the earlier trimesters of pregnancy have suggested that an aberration of steroid metabolism may cause it. Conjugation of bilirubin is normal in these patients, and it is possible that the defect in bile excretion may represent an inborn inability as in the constitutional hyperbilirubinaemias. So far it has not been possible to reproduce the lesion in the experimental animal.

An important question is the relation of intrahepatic cholestasis to the mysterious disease predominantly affecting middle-aged women called primary biliary cirrhosis. ${ }^{12}$ In this condition pruritus and jaundice of insidious onset are followed by some years of reasonable health without evidence of hepatocellular dysfunction. It is apparently not the same as chlorpromazine jaundice. ${ }^{13} 14$

Recognition of intrahepatic cholestasis is of great practical importance. A history of drug taking, alcoholism, or hepatitis should be sought, but usually the clinical picture of obstructive jaundice and severe pruritus does not differ from that produced by extrahepatic obstruction, and biochemical tests of liver function give the same results. Similarly percutaneous liver biopsy may reveal the occasional example of underlying liver disease, but otherwise is not always easy to interpret. ${ }^{18}$ A therapeutic trial of corticosteroids ${ }^{16}$ is the next step, since these drugs will sometimes relieve the obstruction of intrahepatic cholestasis. If diagnosis is still obscure then laparotomy is justified, though some would advocate that it should be preceded by percutaneous transhepatic cholangiography. ${ }^{17}$ The essential point is that operation should not be undertaken lightly. "The arbitrary period of study and medical treatment ... constitutes a hardship for the patient who ultimately proves to have a surgical lesion. However, it is likely to be lifesaving for the patient with medical jaundice in whom early surgical intervention is not only unrewarding but actually dangerous." 18 When no extrahepatic obstruction is found some form of cholangiography is essential, so that if jaundice persists the patient is not subjected to repeated operations.

Popper, H., and Schaffner, F., F. Amer. med. Ass., 1959, 169, 1447.

Popper, H., and Schaffner, F., f. Amer. med. Ass., 1959, 169, 1447.

s Dubin, I. N., Sullivan, B. H., jun., Le Golvan, P. C., and Murphy, L. C., Amer. f. Med., 1960, 29, 55.

- Popper, H., and Schaffner, F., Ann. intern. Med., 1959, 51, 1230.

Svanborg, A., and Ohlsson, S., Amer. F. Med., 1959, 27, 40.

- Summerskill, W. H. J., and Walshe, J. M., Lancet, 1959, 2, 686.

, Schapiro, R. H., and Isselbacher, K. J., New Engl. F. Med., 1963, 268, 708 .

${ }^{8}$ Leevy, C. M., Zinke, M. R., White, T. J., and Gnassi, A. M., Arch. intern. Med., 1953,92, 527.

- Datta, D. V., Sherlock, S., and Scheuer, P. J., Gut, 1963, 4, 223.

10 Bouroncle, B. A., Old, J. W., jun., and Vazques, A. G., Arch. intern. Med., 1962, 110, 872 .

1 Schaffner, F., and Pepper, H., Gastroenterology, 1959, 37, 565.

12 Ahrens, E. H., jun., Payne, M. A., Kunkel, H. G., Eisenmenger, W. J. and Blondheim S. H., Medicine, 1950, 29, 299.

13 Read, A. E., Harrison, C. V., and Sherlock, S., Amer. F. Med., 1961 31, 249.

14 Popper, H., Rubin, E., and Schaffner, F., ibid., 1962, 33, 807.

1s Shorter, R.' G., Paton, A., and Pinniger, J. L., Quart. F. Med., 1959,

16 Johnson, H. C., jun., and Doenges, J. P., Ann. intern. Med., 1956, 44, 589 .

17 Shaldon, S., Barber, K. M., and Young, W. B., Gastroenterology, $1962,42,371$.

18 Hoffbauer, F. W., F. Amer. med. Ass., 1959, 169, 1453. 